\title{
Village Stay Reservation and Management System for Local Tourism Industry
}

\author{
Abidah Mat Taib ${ }^{1 *}$, Nur Athirah Zainuddin², Noorazalia Izha Haron ${ }^{3}$, \\ Nurul Hidayah Ahmad Zukri ${ }^{4}$ \\ ${ }^{1,2,4}$ Faculty of Computer and Mathematical Sciences, \\ Universiti Teknologi MARA, Perlis Branch, Arau Campus, 02600 Arau, Perlis, Malaysia \\ ${ }^{3}$ Academy of Language Studies, \\ Universiti Teknologi MARA, Perlis Branch, Arau Campus, 02600 Arau, Perlis, Malaysia \\ Corresponding author:*abidah@uitm.edu.my \\ Received Date: 31 August 2020 \\ Accepted Date: 16 October 2020
}

\begin{abstract}
Tourism industry in Malaysia is being developed to be better thus, making Malaysia as one of the most attractive countries to visit. Many Village Stays in Malaysia are owned and managed by inexperienced personnel and have inefficient system. Therefore, local products and nearby tourist attractions are unable to be properly advertised or are not made known to the public. So, the objectives of this project are to develop Village Stay Reservation and Management System that caters for the information of the local tourist attraction products and to evaluate Village Stay Reservation and Management System in terms of perceived ease of use. In order to achieve the objectives, this project developed the system using PHP programming language and tested the functionality, usability and user acceptance of the system. Fifteen respondents were involved in the testing of this system. A set of questionnaires was used to collect the data. The mean for user acceptance test is 3.77 while for user reaction in usability testing is 3.74. The respondents are satisfied with the system in terms of its usability. In conclusion, this research has achieved the objectives. It is shown that the users can deal more effectively and efficiently when using this system. This system will reduce the workload of the staffs when using an online system to monitor the reservation as well as attending to other chores.
\end{abstract}

Keywords: village stay, reservation system, tourism industry, web-based Application

\section{INTRODUCTION}

Malaysia is well gifted with plenty of natural resources particularly suitable for sustainable tourism. Besides beautiful beaches, historical places, good infrastructure, and a variety of delicious food options, Malaysians are well known for their extremely friendly, kind and generous traits that makes spending time in many destinations in Malaysia attractive and worth a visit. According to Anowar Hossain Bhuiyan, Siwar, and Mohamad Ismail (2013), tourism is a potential matter in environmental, social, and economic levels under the government agendas. For the government, tourism is one of the tools of development that gives the right to protect the environment and traditions. From January to December 2015, Malaysia welcomed a total of 25.7 million $(25,721,251)$ tourists and RM69.1 billion tourism receipts (Hanafiah \& Ramli, 2016). According to the World Travel and Tourism Council's economic forecast in 2016, tourism and travel directly contributed RM58 billion to the country's Gross Domestic Product (GDP) equalling to 4.7\% of total GDP (Bernhard, Teo, \& Hok Yean, 2017). Hence, the growth of tourism industry can achieve the Malaysia Plan which is to make Malaysia a better country to visit. Tourism industry also helps to increase the income of a country. It suits the $11^{\text {th }}$ Malaysia Plan that has 
the theme of "anchoring growth on people". Hence, it emphasizes the capital economy and people economy.

The definition of capital economy is referring to GDP growth, big businesses, financial markets and investment of projects while the people economy is defined as jobs for people, cost of living, well-being of the family and social inclusion (Leong \& Kasmuri, 2015). Hence, tourism operators who run tourism business tend to have difficulties in accessing the site that they want to visit and publish their products. Having a great data storage of customers can increase the performance of the tour operator's business. Malaysia has many interesting places but the development of the place is not well-known by many people. Similarly, it makes it harder for the managers to improve the management of the place.

Hence, this project used online database for storing the data of the customers. It will systematically arrange the schedule of customers' booking, the renting of the facilities and additionally, improve the management of the place. It also helps to secure the data that have been placed on this site. Therefore, this project proposes a village stay reservation and management system for tourism industry in Malaysia that can be beneficial to many small medium industries or village industry like village stay.

\section{LITERATURE REVIEW}

\section{Web-based Application}

Web-based application is widely used by many people as it can ease their work and help them in streamlining many of the tasks in their daily lives. According to Jazayeri (2007), web-based application is defined as an application that is invoked with a browser over the Internet. Web-based application implements business logic and its use changes the state of the business.

The basic architecture of web-based application includes browsers (client), a database server and a web application server. The browser will request a web page from the server. Each of the web page is a mixed content and formatted instructions are expressed using HTML. Some of it include client side scripts that are interpreted by the browser. A customer or any user can also interact with the system by navigating to different web pages in the system via hyperlinks (Conallen, 1999).

Web server is a computer system that hosts or delivers the web-based application. It will ease the user as the browser will connect to the server and fetch the requested page and respond to the browser. It is essential to have a server that is connected to a fast network as the user does not have to wait for a long time when surfing the Internet.

\section{Village Stay}

Village stay is one of the many tourism attractions for tourists to experience living in the village and involve in local activities or enjoy the service provided to them (Mapjabil, 2015). According to Geneva (2010), tourism can be defined as an economic activity of immense global significance, while Wan (2013) stated that tourism is the temporary of short term movement of people to destinations outside the places where they normally live and work, as well as their activities during their stay at these destinations. The increased desire for nature-based and agro-tourism has improved the rural areas (Mohd Salleh, Othman, Nordin, Mohd Idris, \& Shukor, 2014). The expansion of tourism in the suburbs and rural areas is a result of the growing interest in eco- and agro-tourism. Participation from community is a designed process to create conditions that can generate social and economic progress for the whole community. A sustainable community can help the residents to enhance and protect the environment so that the tourists feel 
comfortable staying in Malaysia (Nor \& Awang, 2017). Village stay also helps Malaysians to enrich their culture and at the same time can show it to the tourists.

\section{Related Works}

Bemile, Achampong, and Danquah (2014) developed their online reservation system using PHP scripting language. PHP was used for the server side scripting language which was basically the queries used to link the website to the database. The authors used Macromedia Dreamweaver to build the web page as it is user friendly and has many features. In addition, Microsoft Internet Explorer was the browser used for the project as it is free to any windows based operating system. Hence, the coding was being implemented on the WAMP which is a stand from an initial operating system Microsoft Windows and principal components of package which are Apache, MYSQL and one of PHP, Perl or Python. Identically, the authors designed the web page where users can gain access to the present website. The authors used the proper colours, font type and size to make reading easy.

In contrast, Delizo and Esguerra (2013) created web sites, web applications and web services using ASP.NET as their server side scripting language. Hence, the system was deployed via the Internet. They used Microsoft Web Developer 2008 as a platform for programming language. Not only Microsoft Visual Web Developer but Microsoft Visual Studio 2005 can also be used to develop powerful ASP.NET web applications as it has various tools for developing web applications. MySQL Server 2005 was used by the authors. Hence, it provided quick access to the data with the combination of Visual Web Developer in order to have a proper display of information. Furthermore, Ping and Dongxiao (2013) proposed to develop a system by using ASP as a server side scripting language. Moreover, the author used IIS5.0 as the web application server and Dreamweaver 2004 MX as the application software development platform.

Comparison of related works with the work presented in this paper is shown in Table 1.

Table 1: Comparison of related works

\begin{tabular}{|c|c|c|}
\hline Author & $\begin{array}{c}\text { Tool and Technology Used to } \\
\text { Develop Online Reservation } \\
\text { System }\end{array}$ & Function of the Proposed System \\
\hline $\begin{array}{l}\text { Bemile, } \\
\text { Achampong, } \\
\text { and } \\
\text { Danquah } \\
(2014)\end{array}$ & $\begin{array}{l}\text { Server side scripting: PHP } \\
\text { Platforms to develop the } \\
\text { system: Macromedia } \\
\text { Dreamweaver and Adobe Flash } \\
\text { Implementation of web } \\
\text { application: WAMP } \\
\text { Deployment of web application: } \\
\text { Microsoft Internet Explorer }\end{array}$ & $\begin{array}{l}\text { - Allow customers to get all the necessary } \\
\text { information about the hotel and its facilities. } \\
\text { - Customers can make their own reservation at } \\
\text { their places rather than going to the resort. } \\
\text { - Customers can send emails to the company. }\end{array}$ \\
\hline $\begin{array}{l}\text { Delizo and } \\
\text { Esguerra } \\
(2013)\end{array}$ & $\begin{array}{l}\text { Server side scripting: ASP.NET } \\
\text { Platform to develop the system: } \\
\text { Microsoft Web Developer } 2008 \\
\text { Implementation of web } \\
\text { application: Windows } \\
\text { Deployment of web application: } \\
\text { Microsoft Internet Explorer }\end{array}$ & $\begin{array}{l}\text { - Provide skill and additional knowledge to } \\
\text { students on how to operate an online hotel } \\
\text { reservation system. } \\
\text { - The delivery of instructions service that is } \\
\text { provided by the college will be better as } \\
\text { faculty members can access the system and } \\
\text { do not have to purchase the same system for } \\
\text { the students. } \\
\text { - A system administrator can monitor and } \\
\text { supervise the accounts that have been created }\end{array}$ \\
\hline
\end{tabular}




\begin{tabular}{|c|c|c|}
\hline & & by the students and clients. \\
\hline $\begin{array}{l}\text { Ping and } \\
\text { Dongxiao } \\
(2013)\end{array}$ & $\begin{array}{l}\text { Server side scripting: ASP } \\
\text { Platform to develop the system: } \\
\text { Dreamweaver } 2004 \text { MX } \\
\text { Web server: IIS } 5.0\end{array}$ & $\begin{array}{l}\text { - The system can give detailed information of } \\
\text { the rooms to the customers. } \\
\text { - The system can record in one complete check- } \\
\text { in course and whole consumption that are } \\
\text { made by the customers. }\end{array}$ \\
\hline $\begin{array}{l}\text { Athirah } \\
\text { (2018) }\end{array}$ & $\begin{array}{l}\text { Server side scripting: PHP } \\
\text { Platform to develop the system: } \\
\text { Notepad++ } \\
\text { Implementation of web } \\
\text { application: XAMPP } \\
\text { Deployment of web application: } \\
\text { Google Chrome } \\
\text { Web server : Apache Web } \\
\text { Server }\end{array}$ & $\begin{array}{l}\text { - Manager can monitor the booking of the } \\
\text { customers. } \\
\text { - Customers can obtain details of the company. } \\
\text {-Customers can get information, promotion and } \\
\text { announcements from the staff through email. }\end{array}$ \\
\hline
\end{tabular}

\section{METHODOLOGY}

The methodology applied in this project is System Development Life Cycle (SDLC) which comprises of six phases as shown in Figure 1. In the requirement and analysis phase, a number of meetings with the stakeholder was held in order to meet the business requirement before designing and prototyping the system. Nevertheless, design phase is important as it affects the development of the project. The activities that were done in this phase are designing the Design Flow Diagram (DFD) and Entity Relationship Diagram (ERD) for the village stay web-based application. Figure 2 shows the ERD for the web application. The ERD which was built using Microsoft Visio 2016, consists of nine tables which are Staff, Customer, Facility, FacilityBook, Booking, Room, RomBook, Service and ServiceBook.

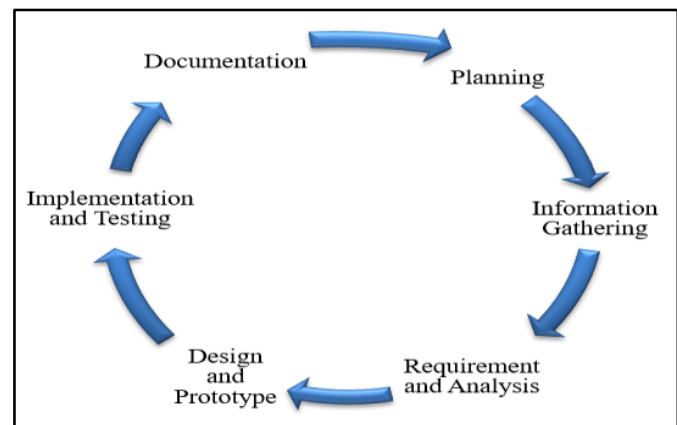

Figure 1: System Development Cycle 


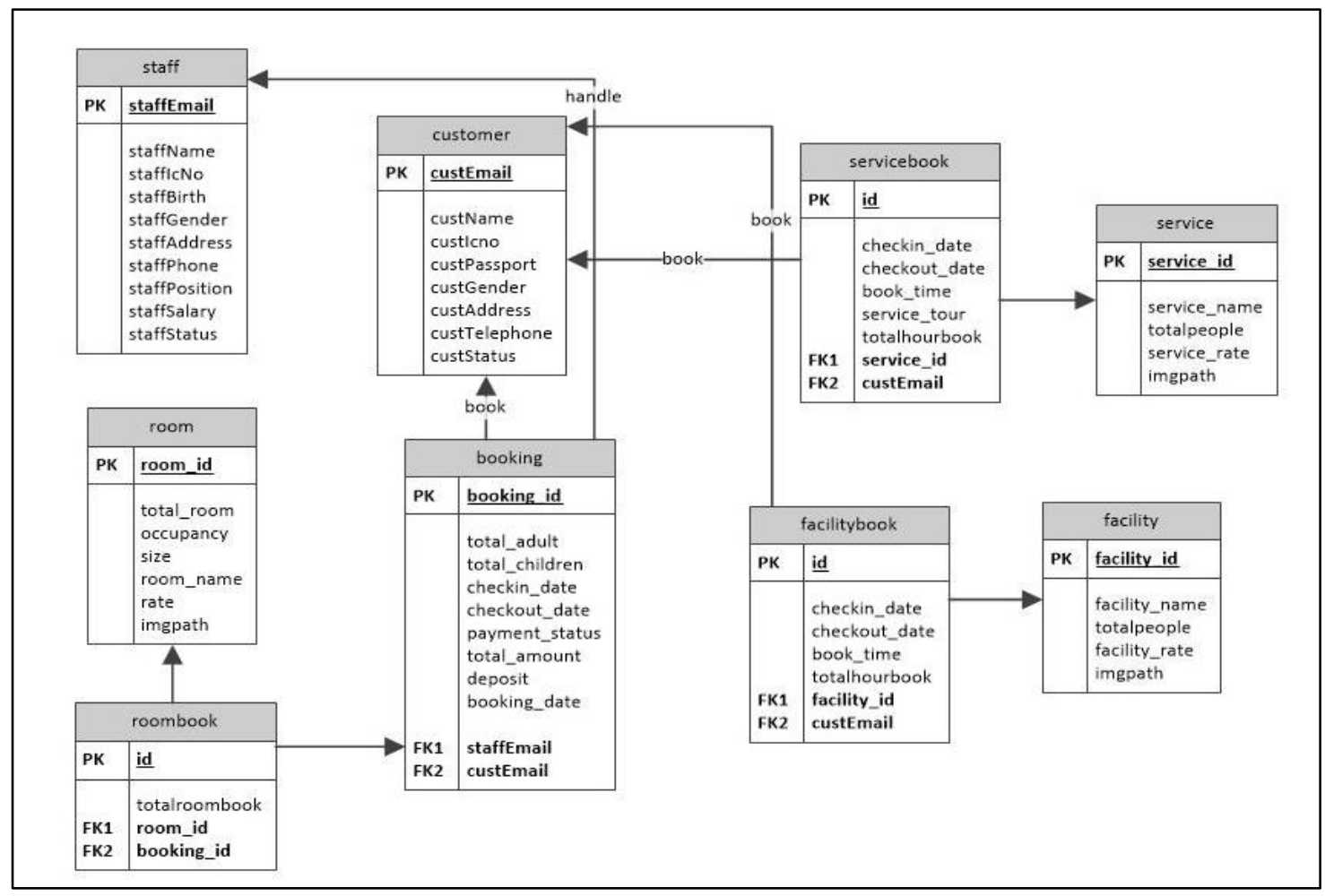

Figure 2: Entity Relationship Diagram

Figure 3 shows the DFD for the web application. The DFD that was built using Microsoft Visio explains the customer's flow of activity. This project involved three main functions which are booking of the rooms, facilities and services. All users of the system must first login in order to use the features of the system. Staffs use the system to manage the customers and the reservation as well as keeping track of the facilities or services provided by the village stay. Once logged in, a customer can browse through the application to view the choice of rooms, services and facilities provided by the village stay and check its availability by checking the dates. After that, the customer can make the reservation and will receive an email confirmation. This project also used 000 webhost as a storage space for the system to be accessed on the network. 


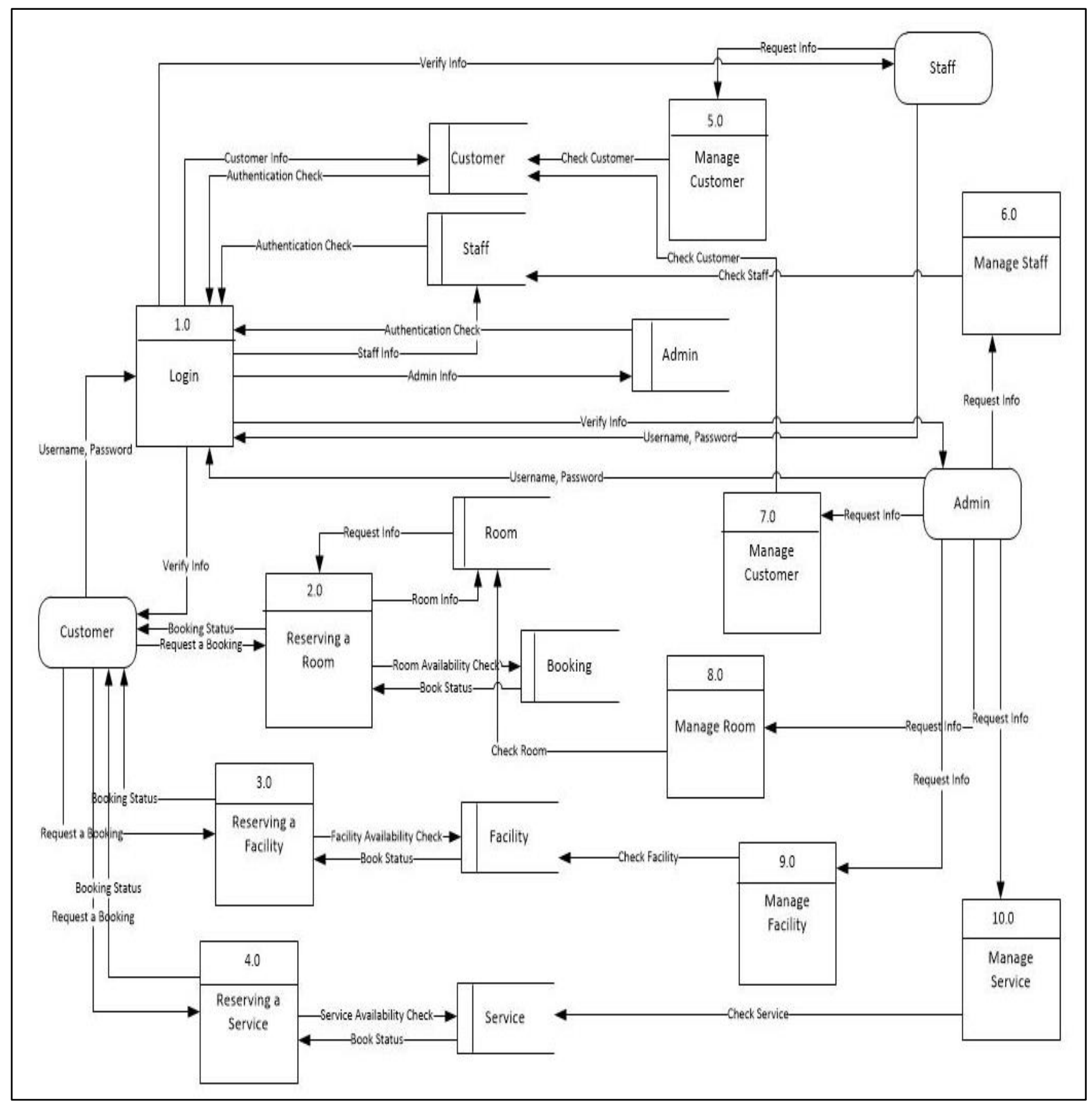

Figure 3: Data Flow Diagram (DFD)

The homepage interface design is shown in Figure 4 while the interface design of the system is shown in Figure 5. These interfaces show the system used to check the availability of the room. The system will inform the users if they do not fill up the form. Hence, the users cannot proceed with the room booking. The system will also inform the users if they do not fill in the form and if they fill in the form using the wrong format of data. Once the data are complete, the system will send a confirmation email to the users. Guests can also use the system to reserve the services and facilities provided by the Village Stay. Figure 6 shows the preferable services for the customers to choose. The management can also refer to the related reports to see the list of bookings such as monthly or yearly reservations as well as associated statistics that may help them improve the services or plan for suitable promotions to attract visitors. 


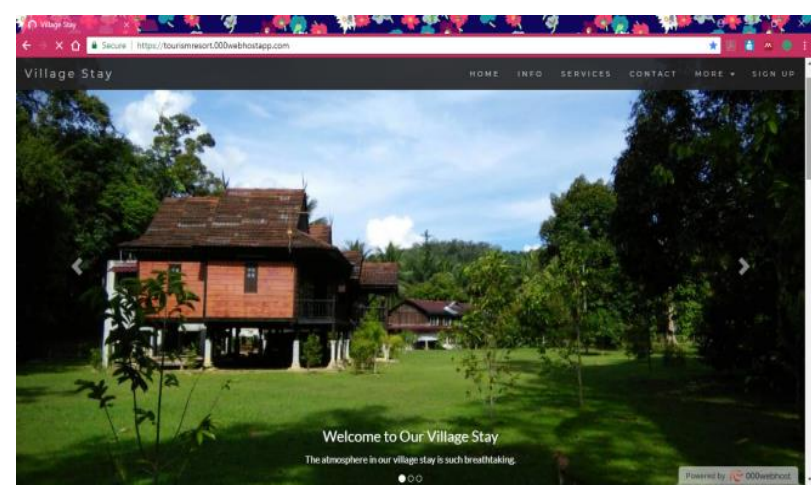

Figure 4: Homepage Interface Design

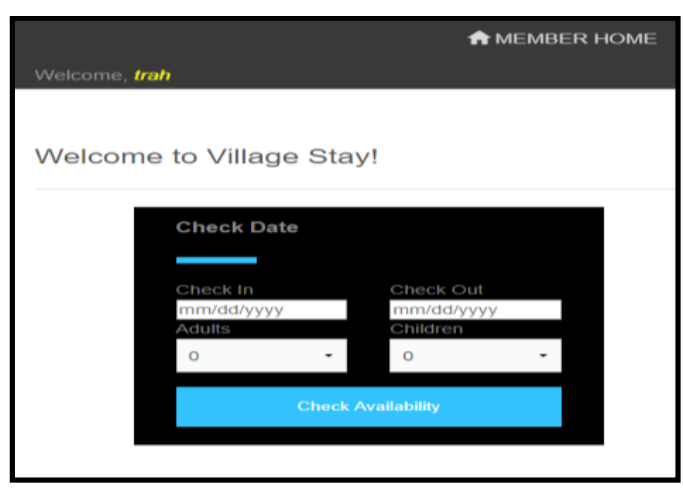

Figure 5: System Interface Design

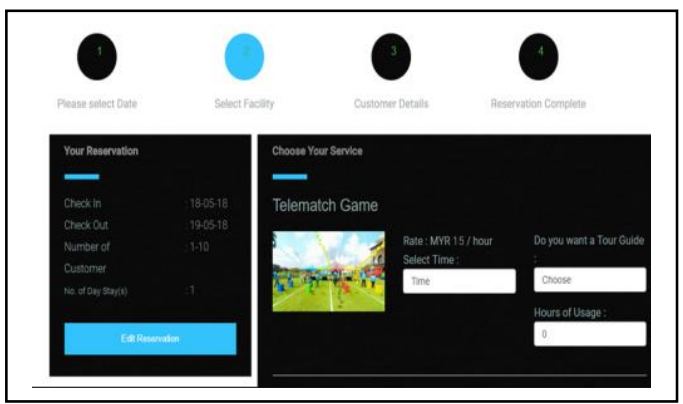

Figure 6: Preferable Services

The web based application is crucial to be tested before it is delivered to the customers and the staff. The developer must conduct a functional test before it is being delivered to the customers. The purpose of functional testing is to test whether all of the components from the web based application can function well or not (Gift, 2009). Several tests were conducted during this phase such as usability test, user acceptance test and performance testing. The system was tested by a group of people so that they could experience the system. According to Adams and Cox (2008), a focus group of people should not exceed six or seven participants. In fact, the more participants exist in the testing, it is more likely for them to break off to talk in sub-groups and leave other participants out of the discussion. This project used a set of questionnaires that was distributed online to the users in order to evaluate the system in terms of its usability and user acceptance. A five (5) Likert scale of 'totally disagree', 'disagree', 'neutral', 'agree' and 'totally agree' was used. The users must first test the system in order to provide their feedback about it. Additionally, the performance testing of the web application was tested using JMeter (Dhiman \& Sharma, 2016).

\section{RESULTS}

Fifteen people who enjoy traveling and visiting places as their hobby were identified as the focus group to test the system. Their feedback were analysed and presented in terms of the types of testing conducted.

\section{Usability Testing}

Usability testing is a testing approach that is used to identify the areas where people normally struggle with a product and can make a recommendation for improvement. 
The bar graph in Figure 7 illustrates the reaction of the users about the system. The figure shows the percentage of 'disagree', 'neutral', 'agree' and 'totally agree' for usability testing. Below are the questions in the questionnaires used for the usability testing:

Q1: The organization of information on the Village Stay Reservation and Management System is clear.

Q2: The Village Stay Reservation and Management System gives error message that clearly tells me to fix the problem.

Q3: The mistake that I make on the Village Stay Reservation and Management System can be fixed easily.

Q4: The site of Village Stay Reservation and Management System is easy to use and the information needed can be easily navigated.

Q5: Overall, I am satisfied with the Village Stay Reservation and Management System.

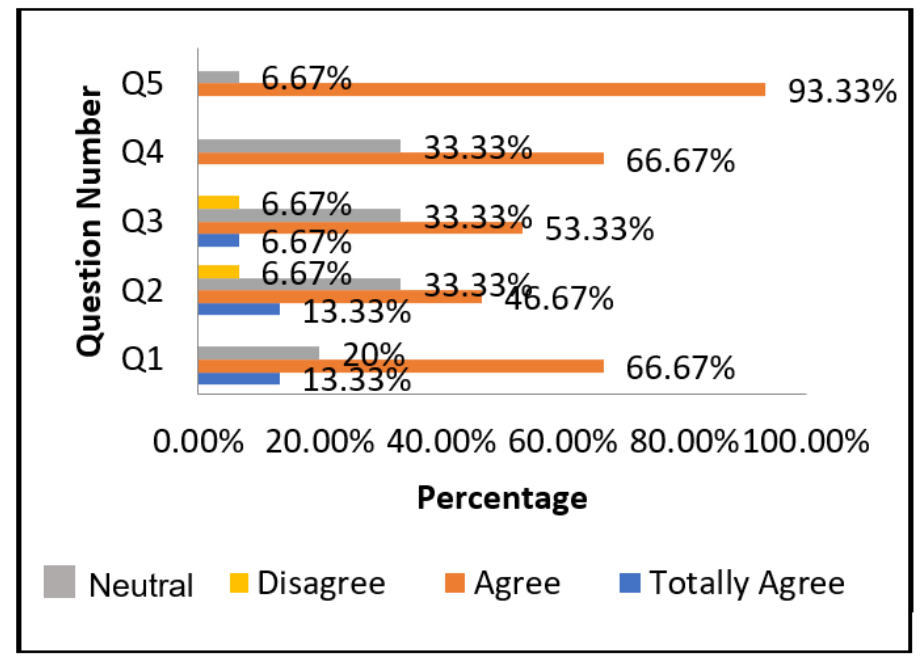

Figure 7: User Reaction about the System

As shown in Figure 7, for each question asked, more than $80 \%$ of the respondents give positive remarks as they are satisfied with the system. It can be inferred that the respondents found the system usable and can benefit them. However, 6.67\% of the respondents disagree to Q2 and Q3 which tells that there are rooms for improvement which need to be considered.

\section{User Acceptance Testing}

Perceived Ease of Use (PEOU)

Figure 8 depicts the user acceptance test in perceived ease of use. Below are the questions asked in perceived ease of use section.

Q1: I think it is easy for me to use the Village Stay Reservation and Management System.

Q2: I think it is easy for me to interact with the Village Stay Reservation and Management System. 
Q3: I think it would be easy for me to become skilful at using the Village Stay Reservation and Management System.

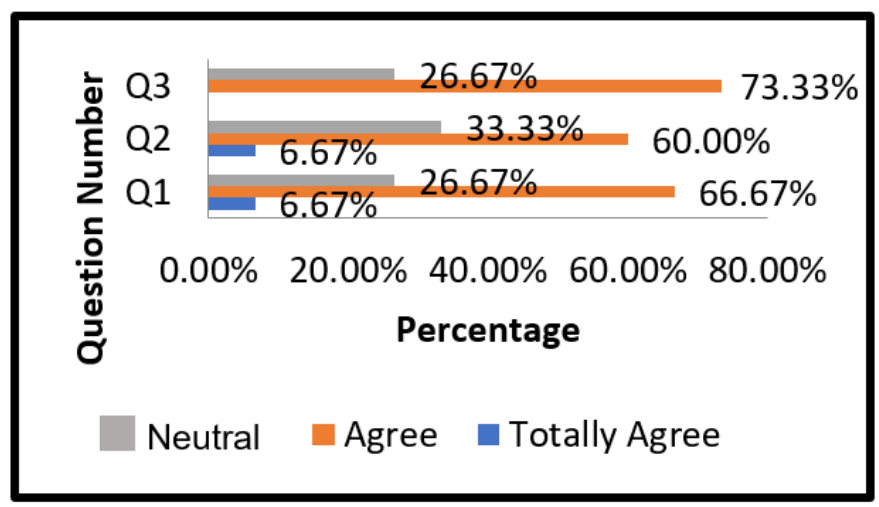

Figure 8: Perceived Ease of Use

As can be seen in Figure 8, generally, about $73.34 \%$ of the respondents find the system easy to use and $66.67 \%$ of the respondents state that it is easy to interact with the Village Stay Reservation and Management System. Others are 'neutral'. As for Q3, 73.33\% of the respondents vote for 'agree' that they will become skillful when using the system and $26.67 \%$ of the respondents vote for 'average'. These findings indicate that in general the respondents' acceptance of this system is very encouraging.

Perceived Usefulness (PU)

Figure 9 depicts the perceived usefulness. Below are the questions asked in the perceived usefulness section.

Q1: $\quad$ The Village Stay Reservation and Management System is useful to me.

Q2: $\quad$ The Village Stay Reservation and Management System improves the efficiency of my life.

Q3: The Village Stay Reservation and Management System enables me to accomplish tasks more quickly.

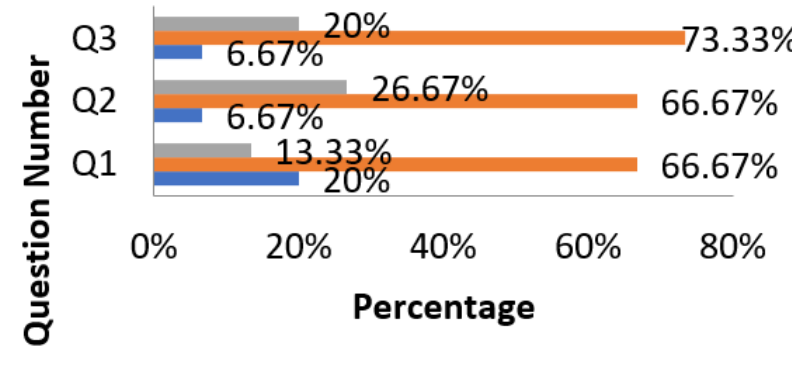

Neutral Agree $\square$ Totally Agree

Figure 9: Perceived Usefulness 
As revealed in Figure 9, although there are some respondents who vote for 'neutral' for the three questions asked, most of them agree that the Village Stay Reservation and Management System is useful to use, improves the efficiency of their life, and can accomplish their tasks quickly.

\section{Performance Testing}

The performance testing of this research used the Apache JMeter to examine the performance of the web server. There are two parameters that were analysed in this research which are throughput and deviations. Having a higher throughput and smaller deviations can have a better performance of the server. The analysis of performance testing is shown in Figure 10.

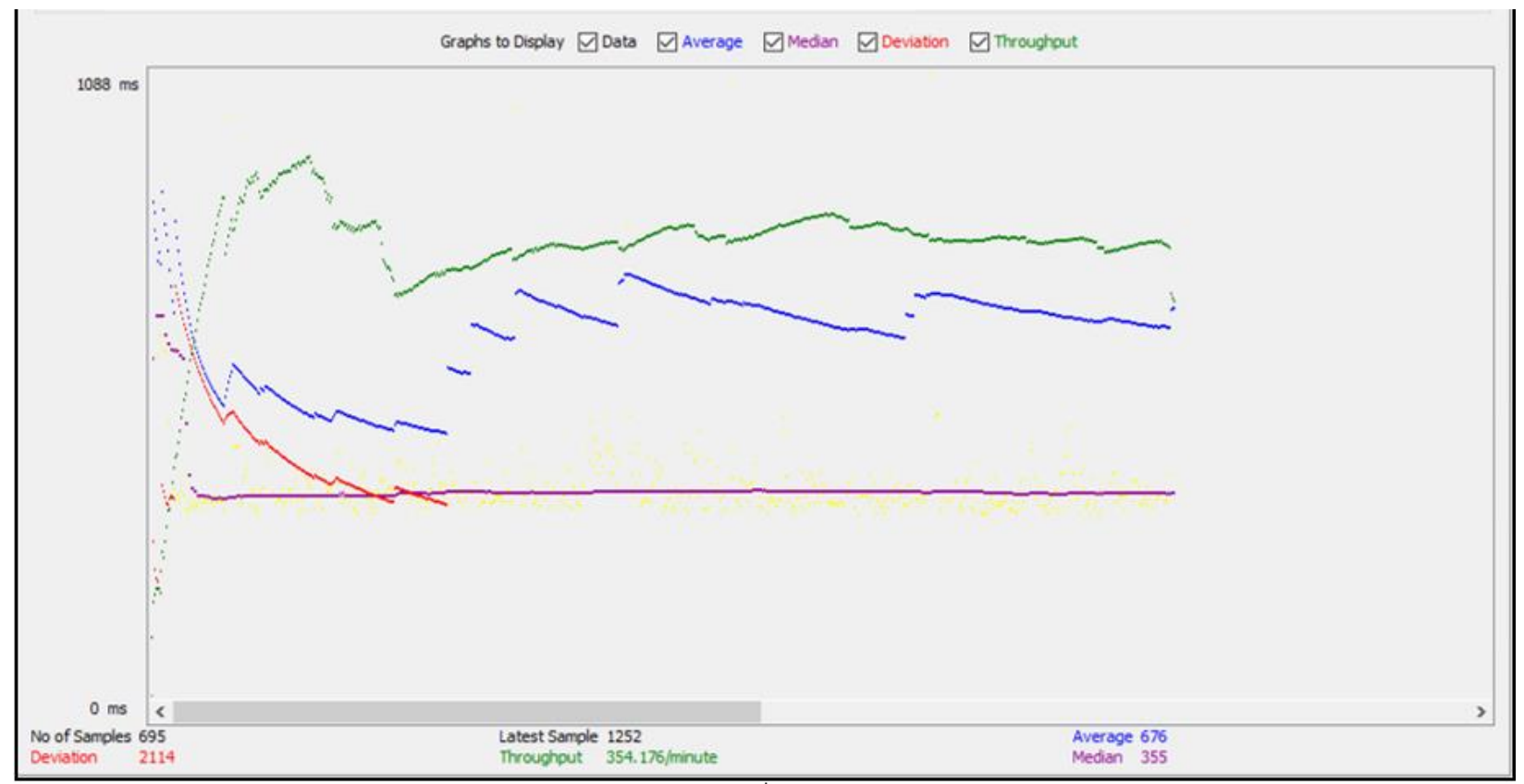

Figure 10: Performance Testing

The throughput line is shown in green while the deviation line is shown in red. In this test, throughput of 000webhost server is 354.176 per minutes which means that 000webhost server can handle 354.176 requests per minute. Meanwhile, the deviation of 000webhost is 2114 . The line deviation shown in Figure 10 is below than the throughput line, which means 000 webhost server has a better performance.

\section{Analysis and Discussion}

Table 2 shows the overall result for the testing. The mean for user acceptance test is 3.83 while for user reaction in usability testing is 3.76. This means that the system should be extended with more features so that the users will be at ease when using the system. Given these points, the users of the system are satisfied as they have given approving feedback.

Table 2: Overall Result

\begin{tabular}{|c|c|c|c|}
\hline Criteria & Min & Max & Mean \\
\hline Usability Testing & 3.6 & 3.93 & 3.76 \\
\hline $\begin{array}{c}\text { User Acceptance } \\
\text { Testing }\end{array}$ & 3.73 & 4.07 & 3.83 \\
\hline
\end{tabular}


The findings have shown that many of the respondents prefer to use an online system in order to book for rooms and other facilities and services. The users can accomplish their tasks using online system quickly. Hence, they do not have to go to the targeted places in order to obtain information or any details of the places as these information or details are already available on the Internet. As for the management, they can view the related report on list of guests, bookings and other data for future planning and for any necessary arrangements.

\section{CONCLUSION AND RECOMMENDATION}

Having an online system can help the public to access the Internet in order to easily search for tourist attractions as well as potential village stay or lodging to experience life in the local culture. Customers of the Village Stay Reservation and Management System can easily choose their rooms and other related services based on their budgets and other preferences. It is shown that the users can deal more effectively and efficiently when using this system. Besides reducing the workload of staffs when using an online system for bookings, this system can be improved to include monitoring of the daily schedule and tasks accomplished as well as suggesting outdoor activities options to the guests. Considering feedback from the users, more features that concern human computer interaction should be integrated into the system to make it more user friendly and increase user satisfaction.

\section{REFERENCES}

Adams, A., \& L. Cox, A. (2008). 2 Questionnaires, in-depth interviews and focus groups. Retrieved from http://oro.open.ac.uk/11909/1/9780521870122c02_p17-34.pdf

Anowar Hossain Bhuiyan, M., Siwar, C., \& Mohamad Ismail, S. (2013). Tourism Development in Malaysia from the Perspective of Development Plans. Asian Social Science, 9(9). https://doi.org/10.5539/ass.v9n9p11

Bemile, R., Achampong, A., \& Danquah, E. (2014). Online Hotel Reservation System. International Journal of Innovative Science, Engineering \& Technology, 1(9). Retrieved from http://www.ijiset.com/v1s9/IJISET_V1_I9_92.pdf

Bernhard, S., Teo, H., \& Hok Yean, C. (2017, May). In Focus: Malaysia - A Rising Opportunity | By Stephanie Bernhard, Hatta Teo and Hok Yean CHEE - Hospitality Net. Retrieved October 23, 2017, from https://www.hospitalitynet.org/opinion/4082735.html

Conallen, J. (1999). Modelling Web Application Architectures With UML, 42(10), 63-70. Retrieved from https://pdfs.semanticscholar.org/efae/664ef829b052237d86a2e43ace653a2b24fd.pdf

Delizo, G. A., \& Esguerra, M. A. (2013). Online Hotel Reservation and Management System for the College of International Tourism and Hospitality Management (CITHM). Journal: International Journal of Computers \& Technology, 10(1), 1201-1229. Retrieved from http://research.lpubatangas.edu.ph/wp-content/uploads/2014/05/IJCT-Online-Hotel-Reservation.pdf

Dhiman, S., \& Sharma, P. (2016). Performance Testing: A Comparative Study and Analysis of Web Service Testing Tools. International Journal of Computer Science and Mobile Computing, 56(6), 507-512. Retrieved from https://www.ijcsmc.com/docs/papers/June2016/V5I6201697.pdf

Geneva. (2010). Developments and challenges in the hospitality and tourism sector. Retrieved from http://www.ilo.org/wcmsp5/groups/public/@ed_norm/@relconf/documents/meetingdocument/wcms 
_166938.pdf

Gift, N. (2009). Functional testing for Web applications. Retrieved May 25, 2018, from https://www.ibm.com/developerworks/web/library/wa-aj-testing/

Hanafiah, S., \& Ramli, A. R. (2016). Tourism Malaysia. Retrieved October 16, 2017, from http://www.tourism.gov.my/pdf/uploads/cc1a98fe-a4d6-4b9c-b3c9-7269772e7aaf.pdf

Jazayeri, M. (2007). Some Trends in Web Application Development. In Future of Software Engineering (FOSE '07) (pp. 199-213). IEEE. https://doi.org/10.1109/FOSE.2007.26

Leong, L. M., \& Kasmuri, A. (2015). 1th Malaysia Plan 11-MP (2016-2020) 11th Malaysia Plan: The Final Countdown Developing \&quot; capital economy \&quot; and \&quot; people economy \&quot; through six strategic thrusts, (5). Retrieved from http://iskandarmalaysia.com.my/newsletter/IM BizWatch May 2015.pdf

Mapjabil, J., Che Ismail, S., Ab Rahman, B., Masron, T., Ismail, R., Mohd Zainol, R., ... Sains Sosial dan Kemanusiaan, F. (2015). Homestays -Community programme or alternative accommodation? A reevaluation of concept and execution. Retrieved from http://www.ukm.my/geografia/images/upload/1.geografia-si-nov15-jabil-edam.pdf

Mohd Salleh, N., Othman, R., Nordin, N., Mohd Idris, H., \& Shukor, M. S. (2014). The Homestay Program in Malaysia: Motivation for Participation and Development Impact. Tourism: International Scientific and Professional Journal, Vol. 62 No. 4. Retrieved from https://translate.google.com/translate?hl=en\&sl=hr\&u=https://hrcak.srce.hr/131939\&prev=search

Nor, S. M., \& Awang, K. W. (2017). Challenges Faced By Operators To Sustain Homestay Businesses In Selangor, Malaysia. Cjt1 1 International Journal of Innovation in Social Sciences, 2(1). Retrieved from http://kmc.unitar.my/doc/ijissvol2/2106_sarina.pdf

Ping, H., \& Dongxiao, G. (2013). Development and Implementation of WEB - based Online Hotel Reservation System. https://doi.org/10.2991/isccca.2013.58

Wan, C. (2013). Tourism and Hospitality Studies Introduction to Tourism. Hong Kong. Retrieved from http://www.edb.gov.hk/attachment/en/curriculum-development/kla/pshe/nss-curriculum/tourismand-hospitality-studies/Tourism_English_19_June.pdf

Yi, M. Y., Jackson, J. D., Park, J. S., \& Probst, J. C. (2006). Understanding information technology acceptance by individual professionals: Toward an integrative view. Information and Management, 43(3), 350-363. https://doi.org/10.1016/j.im.2005.08.006 